\title{
ANALISIS BAHAYA, KERENTANAN DAN RISIKO BENCANA TSUNAMI DI PROVINSI PAPUA BARAT
}

\section{ANAL YSIS FOR HAZARD, VULNERABILITY AND TSUNAMI DISASTER RISK IN WEST PAPUA PROVINCE}

\author{
Heru Sri Naryanto ${ }^{1}$ \\ ${ }^{1}$ Pusat Teknologi Reduksi Risiko Bencana (PTRRB), Badan Pengkajian dan Penerapan \\ Teknologi (BPPT), Gedung Geostech, Kompleks Puspiptek, Serpong, Kota Tangerang Selatan / \\ Gedung 2 BPPT, Lantai 12, JI. MH Thamrin 8, Jakarta 10340 \\ e-mail: heru.naryanto@bppt.go.id
}

\begin{abstract}
The meeting of the 3 world plates, the Eurasian Plate, the Indo-Australian Plate, and the Pacific Plate in eastern Indonesia, caused a high potential for earthquake and tsunami events in the area. The frequency of tsunami events in eastern Indonesia including West Papua Province is quite large. Tsunamis are mostly caused by earthquakes originating from the sea, but can also be triggered by submarine landslides, volcanic eruptions at sea, gas extrusions, celestial bodies, nuclear explosions and other generating sources. With the high potential of tsunamis in West Papua Province, tsunami hazard and risk maps are urgently needed to become a reference in the development planning process and tsunami disaster risk reduction measures that are more effective, efficient and integrated to reduce the possible impact of victims. The danger of a high tsunami in West Papua Province which has a far enough landward direction is on the coast of Sorong City, Sorong District, South Sorong District, Bintuni District and north of Fakfak District (Bomberay Sub-District). Based on the area of high-risk areas, Bintuni District is the district that has the widest high-risk area, with an area of $116,728 \mathrm{Ha}$ or $5.61 \%$ of the total area of the Bintuni District, while Tambrauw District is the district with the smallest high risk area of 2,076 $\mathrm{Ha}$ or $0.32 \%$ of the total area. The only district that does not have a tsunami threat because it is not in the coastal area is Maybrat District.
\end{abstract}

Keywords: tsunami, West Papua, hazard, risk, risk reduction

\begin{abstract}
ABSTRAK
Pertemuan 3 lempeng dunia, Lempeng Eurasia, Lempeng Indo-Australia, dan Lempeng Pasifik di Indonesia bagian timur, menyebabkan potensi tinggi kejadian gempa dan tsunami di daerah tersebut. Frekuensi kejadian tsunami di Indonesia bagian timur termasuk Provinsi Papua Barat cukup besar. Tsunami sebagian besar disebabkan oleh gempabumi bersumber di laut, tetapi juga bisa dipicu akibat tanah longsor bawah laut, letusan gunungapi di laut, ekstrusi gas, benda-benda langit, ledakan nuklir dan sumber pembangkit lainnya. Dengan tingginya potensi tsunami di Provinsi Papua Barat, maka sangat dibutuhkan peta bahaya dan risiko tsunami untuk menjadi acuan dalam proses perencanaan pembangunan serta kegiatan pengurangan risiko bencana tsunami yang lebih efektif, efsien dan terpadu untuk mengurangi dampak korban yang mungkin terjadi. Bahaya tsunami tinggi di Provinsi Papua Barat yang mempunyai pelamparan cukup jauh ke arah daratan terdapat di pantai Kota Sorong, Kabupaten Sorong, Kabupaten Sorong Selatan, Kabupaten Bintuni dan sebelah utara Kabupaten Fakfak (Kecamatan Bomberay). Berdasarkan luas area berisiko tinggi, Kabupaten Bintuni merupakan kabupaten yang memiliki area berisiko tinggi terluas, yaitu dengan luas $116.728 \mathrm{Ha}$ atau $5,61 \%$ dari luas keseluruhan Wilayah Kabupaten Bintuni, sedangkan Kabupaten Tambrauw merupakan kabupaten dengan wilayah berisiko tinggi paling kecil dengan luas $2.076 \mathrm{Ha}$ atau $0,32 \%$ dari seluruh luas wilayahnya. Satu-satunya kabupaten yang tidak
\end{abstract}


memiliki ancaman tsunami karena tidak berada pada kawasan pesisir adalah Kabupaten Maybrat.

Kata kunci: tsunami, Papua Barat, bahaya, risiko, pengurangan risiko

\section{PENDAHULUAN}

Potensi bencana tsunami di Indonesia sangat tinggi. Indonesia menduduki peringkat kedua sebagai negara yang paling sering dilanda tsunami dengan 71 kejadian atau hampir $9 \%$ dari jumlah tsunami di dunia. Potensi tinggi tersebut karena letak geografis Indonesia yang berada pada pertemuan tiga lempeng utama pembentuk kerak bumi, yaitu Lempeng Eurasia yang bergerak ke arah tenggara dan Lempeng Indo-Australia yang bergerak di Samudera India dari arah utara (Aceh) hingga sekitar Laut Timor di timur dan Lempeng Pasifik yang bergerak di bagian timur Indonesia (Pratomo \& Rudiarto, 2013) Menurut Kementerian Pekerjaan Umum (2017), potensi gempa yang terjadi di Provinsi Papua Barat sebagian besar termasuk katagori sedang sampai tinggi. Potensi gempa yang tinggi tersebut bisa juga berpotensi terhadap tsunami.

Frekuensi kejadian tsunami yang terjadi di Indonesia bagian timur cukup besar, khususnya sejak tahun 1975 dan semakin menegaskan bahwa kompleksnya tatanan tektonik di daerah ini menyimpan potensi tsunami yang cukup besar. Karakteristik gempa pembangkit tsunami di Indonesia menunjukkan bahwa $67 \%$ tsunami berada di Indonesia bagian timur yang tersebar merata dari Sulawesi sampai Papua dan dari Timor sampai Kepulauan Sangihe Talaud (Rahmawati et al., 2017).

Tsunami sebagian besar disebabkan oleh gempabumi di dasar laut. Selain itu tsunami juga bisa dipicu akibat tanah longsor di dasar laut, letusan gunungapi dasar laut, ekstrusi gas, benda-benda langit, ledakan nuklir dan sumber pembangkit lainnya. Di Indonesia kejadian tsunami sebagian besar disebabkan oleh gempabumi. Kejadian gempa sangat berpotensi memicu longsoran bawah laut, dan banyak yang tidak menyadari akan kejadian ikutan tersebut, sebab tempat kejadian longsoran sulit ditentukan posisinya. $\mathrm{Hal}$ inilah yang menjadi salah satu penyebab salahnya estimasi tinggi run-up tsunami hasil perhitungan simulasi tsunami dengan kenyataan di lapangan (Latief, 2000; Puspito, 2002).

Berdasarkan pengalaman historis, kejadian tsunami sangat membahayakan bagi komunitas masyarakat di wilayah pesisir pantai, meskipun daerah tersebut jauh dari kawasan yang rawan bawah laut. Dampak yang dapat ditimbulkan akibat bencana tsunami sangatlah besar, yaitu dapat berupa kematian, kehilangan harta benda, kehancuran sarana dan prasarana khususnya di daerah pesisir pantai, menimbulkan gangguan ekonomi dan bisnis, bahkan dapat mengganggu keadaan psikologis (traumatic) masyarakat (Pratomo \& Rudiarto, 2013).

Provinsi Papua Barat terletak pada $0^{\circ}$, 0 " hingga $4^{\circ}, 0^{\prime \prime}$ Lintang Selatan dan $124^{\circ}, 00^{\prime \prime}$ hingga $132^{\circ}, 0^{\prime \prime}$ Bujur Timur, tepat berada di bawah garis Katulistiwa dengan ketinggian 0 -100 meter dari permukaan laut. Luas wilayah Provinsi Papua Barat mencapai 97.024,37 $\mathrm{Km}^{2}$, dibagi menjadi 10 kabupaten dan 1 kota, yang terdiri atas 154 kecamatan, dan 1.361 desa. Berdasarkan kelas lereng, wilayah Provinsi Papua Barat dapat dibagi menjadi: kemiringan $0-15 \% \quad(45,44 \%)$, kemiringan $15-40 \%(4,24 \%)$, dan kemiringan $>40 \%(50,31 \%)$. Wilayah Provinsi Papua Barat memiliki kelas lereng $>40 \%$ dengan bentuk wilayah berupa perbukitan yang cukup besar (1.069.807,15 Ha) (BPS Provinsi Papua Barat, 2018). Banyaknya pantai yang padat penduduk di wilayah Provinsi Papua Barat, menyebabkan tingginya bahaya dan risiko bencana tsunami.

Gempa merupakan bencana alam yang sampai saat ini masih sangat sulit dan kompleks untuk diprediksi kapan bencana tersebut akan terjadi dalam hitungan yang sangat detail. Kejadian gempa-gempa besar yang pernah terjadi di Indonesia dalam beberapa tahun terakhir, mengisyaratkan bahwa upaya preventif belum dilakukan dengan baik sehingga dampak dari korban masih tinggi (Naryanto, 2008). Hal ini berbeda dengan tsunami terutama yang diakibatan oleh gempa, monitoring bisa dilakukan sehingga pembangunan sistem peringatan dini tsunami sangat penting 
dilakukan untuk mengurangi dampak korban yang mungkin terjadi.

Sesuai dengan UU No 24 Tahun 2007, pembentukan BNPB di pusat dan BPBD di daerah diharapkan penanggulangan bencana dapat dilaksanakan dengan lebih terarah, terpadu, menyeluruh, efisien serta terkoordinasi. Untuk meningkatkan berlangsungnya peran dan fungsi BPBD, maka pengkajian terhadap aspek kebencanaan dalam setiap rencana pembangunan wajib dilakukan, mulai dari yang bersifat makro-politis sampai dengan yang bersifat mikro-teknis (Naryanto, 2017). Sejalan dengan keberadaan BPBD Provinsi Papua Barat, penanggulangan bencana diharapkan juga dapat dilaksanakan dengan lebih baik serta terkoordinasi dengan instansi terkait. Tantangan yang $\mathrm{masih}$ dihadapi adalah keterbatasan ketersediaan data dan informasi tentang kebencanaan di wilayah tersebut.

Adapun tujuan pembuatan peta potensi bahaya dan risiko tsunami Provinsi Papua Barat adalah untuk menjadi acuan dalam proses perencanaan pembangunan di Provinsi Papua Barat, serta kegiatan pengurangan risiko bencana tsunami yang lebih efektif, efsien dan terpadu untuk mengurangi dampak korban yang mungkin terjadi baik jiwa maupun harta.

\section{METODE PENELITIAN}

\subsection{Metode Umum}

Metode penelitian dalam pembuatan peta bahaya, kerentanan dan risiko bencana di Provinsi Papua Barat dilaksanakan sebagai berikut:

- Koordinasi dengan instansi terkait.

- Pengumpulan data sekunder dan referensi terkait.

- Pengumpulan data primer langsung di lapangan.

- Pengolahan dan analisis data secara spasial/ kualitatif/ kuantitatif.

- Validasi data.

- Penyusunan dokumen profil bencana dan peta potensi bahaya gempabumi dan tsunami.
- Evaluasi data.

- Penyelesaian data.

- Pembuatan laporan.

Metodologi yang digunakan dalam penyusunan peta bahaya, kerentanan dan risiko bencana tsunami di Provinsi Papua Barat ditempuh melalui analisis teknis dengan menggunakan bantuan perangkat lunak ArcGIS. Keluaran dari analisis tersebut akan dituangkan ke dalam peta bahaya, peta kerentanan dan peta risiko.

\subsection{Metode Pembuatan Peta Bahaya, Kerentanan dan Risiko Bencana Tsunami}

Metodologi pembuatan peta bahaya, kerentanan dan risiko bencana tsunami di Provinsi Papua Barat, melalui pertimbangan berbagai parameter, yaitu:

- DEM SRTM 30 meter

- Topografi pantai

- Batimetri kawasan pantai

- Sumber gempa penyebab tsunami

- Konfigurasi bentuk pantai

- Sejarah kejadian tsunami

Sebagai dasar utama dalam menentukan zonasi potensi bencana tsunami secara umum adalah dengan menggunakan Peraturan Kepala BNPB No. 02 Tahun 2012 tentang Pedoman Umum Pengkajian Risiko Bencana (BNPB, 2012). Pembagian zona bahaya juga bisa dibedakan berdasarkan kondisi bentuk dan kondisi pantai setempat. Selanjutnya, bagan alir dalam analisis zona bahaya tsunami digambarkan sebagai berikut:

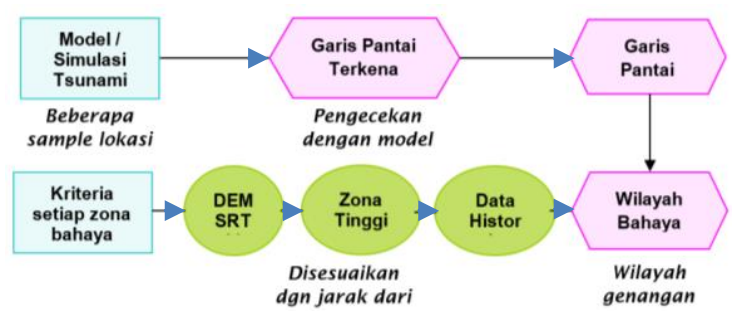

Gambar 1. Bagan Alir dalam Analisis Zona Bahaya Tsunami 
Tabel 1. Kriteria penentuan bahaya tsunami menurut BNPB (2012)

\begin{tabular}{l|r|c|c|c}
\hline \multirow{2}{*}{ Komponen/Indikator } & \multicolumn{3}{|c|}{ Kelas indeks } & \multirow{2}{*}{ Bahan rujukan } \\
\cline { 2 - 4 } & Rendah & Sedang & Tinggi & \\
\hline $\begin{array}{l}\text { Peta Estimasi Ketinggian } \\
\text { Genangan Tsunami/ } \\
\text { Peta Bahaya Tsunami }\end{array}$ & $<1$ meter & $1-3$ meter & $>3$ meter & $\begin{array}{l}\text { Panduan dari Badan } \\
\text { Geologi Nasional- } \\
\text { ESDM dan BMKG }\end{array}$ \\
\hline
\end{tabular}

Keberadaan data kerentanan yang tersedia di Provinsi Papua Barat cukup bervariasi dari satu kabupaten dengan kabupaten lainnya. Dengan demikian maka akan lebih baik bila data yang dipakai adalah seragam yang tersedia hampir atau bahkan ada di semua daerah. Terkait dengan hal tersebut, maka untuk analisis kerentanan kasus Provinsi Papua Barat digunakan data penduduk. Data jumlah penduduk yang tersedia di seluruh daerah di Papua Barat dalam unit area kecamatan dan data inilah yang akan dipakai sebagai parameter kerentanan.

Tidak semua bahaya yang ada dapat menimbulkan risiko bencana. Konsep dasar risiko bencana merupakan fungsi dari bahaya yang terjadi pada suatu daerah yang memiliki kondisi rentan. Elemen kerentanan terdiri dari aspek kelemahan dan kapasitas. Kerentanan merupakan kondisi yang menyebabkan ketidakmampuan menghadapi bahaya (misalnya; keadaan infrastruktur, sosial masyarakat, kerapuhan ekonomi, keadaan lingkungan). Sedangkan kapasitas merupakan sumberdaya atau kekuatan dalam menghadapi bencana (budaya sadar bencana, kesiapan masyarakat, dan kebijakan) (BNPB, 2012). Fungsi dari risiko bencana dapat digambarkan sebagai berikut:

$$
\text { Risiko }=\frac{\text { Bahaya } x \text { Kerentanan }}{\text { Kapasitas }}
$$

Dalam penelitian ini, untuk pembuatan peta risiko bencana menggunakan faktor bahaya dan kerentanan dan tidak menggunakan faktor kapasitas sebagai bahan analisis.

\section{HASIL DAN PEMBAHASAN}

\subsection{Tektonik Indonesia Timur}

Indonesia merupakan daerah pertemuan 3 lempeng tektonik besar, yaitu lempeng Indo-Australia, Eurasia dan lempeng Pasifik. Lempeng Indo-Australia bertemu dengan lempeng Eurasia di Indonesia bagian barat, sementara di Indonesia bagian timur 3 lempeng tektonik berbenturan satu dengan yang lain. Bagian timur Palung Busur Sunda yang merupakan bagian lempeng besar Eurasia, terdesak karena bergeraknya Australia ke utara, sedangkan lempeng Pasifik mendorong ke barat. Hal inilah yang menjadikan tatanan tektonik Indonesia bagian timur lebih rumit dibandingkan dengan yang ada di Indonesia Barat. Di sekitar lokasi pertemuan lempeng ini akumulasi energi terkumpul sampai suatu kondisi dimana lapisan bumi tidak lagi sanggup menahan akumulasi energi sehingga lepas menjadi gempa.

Secara tektonik, Provinsi Papua termasuk ke dalam klasifikasi aktivitas tektonik yang sangat aktif, yaitu dengan adanya zona subduksi di sebelah utara pantai Papua dan adanya sesar/ patahan besar seperti patahan Sorong, patahan Yapen, patahan Ransiki, patahan YakatiYamur dan patahan Tarera-Aiduna (Prawiradisastra \& Santoso, 1997).

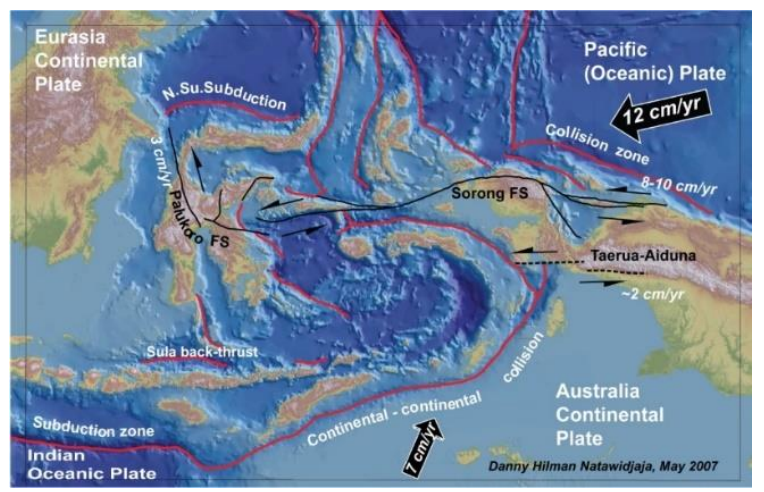

Gambar 2. Peta Tektonik Aktif Indonesia Timur yang Memperlihatkan Batas-Batas Lempeng dan Jalur Patahan Aktif Besar (Natawidjaja, 2007)

Wilayah Papua ditempati oleh tiga jalur besar gempabumi, yakni: Zona pertemuan lempeng Pasifik dan Papua New Guinea yang kompleks, jalur Patahan Sorong dan 
Patahan Tarera-Aiduna. Dengan kecepatan gerak relatif lempeng Pasifik sekitar 120 $\mathrm{mm} / \mathrm{tahun}$, diperkirakan wilayah ini mempunyai potensi bencana gempa sekitar dua-kali lipat lebih besar dibandingkan wilayah Sumatra-Jawa yang pergerakan lempengnya hanya 50-60 mm/tahun. Patahan geser Sorong menurut pengukuran survey GPS yang sudah dilakukan mempunyai laju pergerakan sampai 100 $\mathrm{mm} / \mathrm{tahun}$ (Puntodewo et al., 1994; Natawidjaja, 2007).

\subsection{Kegempaan dan Tsunami di Indonesia Bagian Timur}

\subsubsection{Kegempaan}

Aktivitas tektonik yang tinggi di Indonesia menyebabkan tingkat kegempaan juga tinggi. Gempa yang terjadi di Indonesia dikategorikan menjadi tiga, yaitu gempa yang berasosiasi dengan penunjaman lempeng (zona subduksi), gempa akibat patahan yang bergerak dan gempa vulkanik. Gempa yang berkaitan dengan penunjaman lempeng, jalur gempa yang terjadi mengikuti zona penunjaman yang ada.

Sebagian besar gempa di Indonesia biasanya dapat digolongkan ke dalam gempa tektonik yang berasosiasi dengan perbatasan lempeng. Gempa yang berasosiasi dengan lempeng yang menunjam di bawah lempeng lain, disebut sebagai gempa subduksi. Gempa tersebut rata-rata mempunyai kedalaman antara 30 sampai $700 \mathrm{~km}$.

Engdahl (2006) berusaha melakukan plotting terhadap gempa-gempa dengan skala lebih dari 5 SR yang terjadi dalam kurun waktu 1964 sampai 2006 di wilayah Indonesia bagian timur. Selain titik-titik gempa, Engdahl juga mencantumkan kedalaman pusat gempanya. Dari hasil plotting yang dilakukannya terlihat bahwa pusat gempa di daerah Laut Banda bagian timur terjadi pemusatan kedalaman gempa di daerah tengah yang memanjang mengikuti batas pertemuan lempeng. Demikian halnya dengan kejadian gempabumi yang terdapat di daerah Papua.

Sementara hasil analisis data gempa Skala 5-8 SR dengan memanfaatkan data gempa USGS pada rentang waktu tahun 1900 sampai sekarang (2019) didapatkan hasil yang tidak jauh berbeda dengan analisis Engdahl.

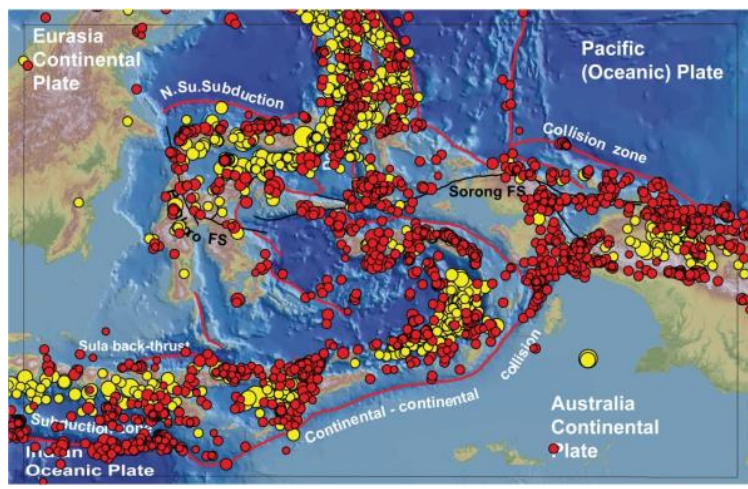

Gambar 3. Sebaran Episentrum Gempa >5 SR yang Terjadi Dalam Kurun 1964-2006 (Engdahl, 2006) $<30 \mathrm{~km}$ depth ; 30 $60 \mathrm{~km}$

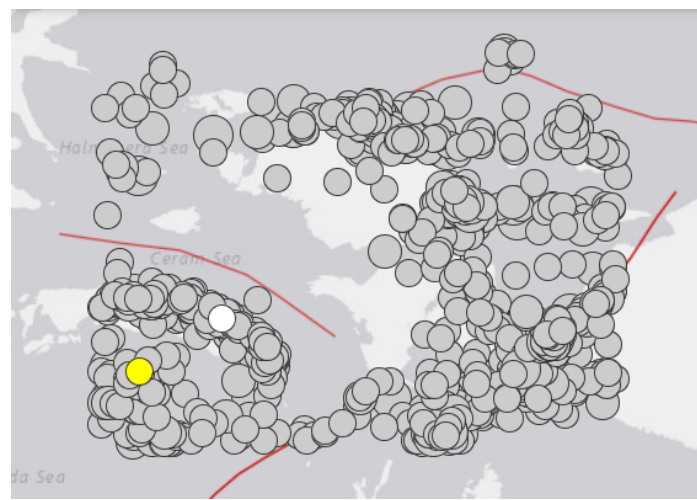

Gambar 4. Peta Sejarah Kegempaan di Wilayah Provinsi Papua Barat dan Sekitarnya Skala 5-8 SR Tahun 1900-2019 (Sumber: Analisis Data Berdasarkan Data Gempa dari USGS).

Populasi penduduk di wilayah Papua saat ini masih sedikit demikian juga infrastrukturnya masih kurang, sehingga walaupun bahayanya paling tinggi di wilayah Indonesia tapi risikonya masih tidak terlalu tinggi. Namun perlu dingat bahwa faktor risiko bencana ini akan terus naik sejalan dengan laju populasi dan pembangunan, yang kalau tidak mengindahkan faktor bencana akan terus mengisi daerah-daerah yang rawan bencana (Natawidjaya, 2007). Salah satu usaha yang paling baik dalam mengantisipasi bencana yaitu dengan melakukan mitigasi bencana (Hadi et al., 2012).

\subsubsection{Tsunami}

Tsunami merupakan serangkaian gelombang panjang yang timbul karena adanya perubahan dasar laut atau 
perubahan badan air yang terjadi secara tibatiba dan impulsif. Tsunami umumnya menerjang pantai landai. Menurut KLH (2007), tsunami ditimbulkan oleh adanya deformasi pada dasar lautan, terutama perubahan permukaan dasar lautan dalam arah vertikal. Perubahan pada dasar lautan tersebut akan diikuti dengan perubahan permukaan lautan, yang mengakibatkan timbulnya penjalaran gelombang air laut secara serentak tersebar ke seluruh penjuru mata-angin.

Provinsi Papua Barat mempunyai potensi tinggi terhadap bencana tsunami. Hampir di semua pantai yang mengelilingi Papua Barat berpotensi untuk terjadi bencana tsunami, mengingat bahwa sumber gempa penyebab tsunami bisa berasal dari perairan bukan hanya wilayah Papua Barat tetapi juga dari perairan di sekitarnya termasuk di luar Indonesia. Pantai yang relatif datar dan berupa teluk akan mempunyai potensi sangat tinggi. Bentuk teluk akan mempercepat pergerakan gelombang tsunami akibat penyempitan daerah, sehingga akan berdampak lebih parah dibandingkan dengan pantai yang relatif panjang.

Menurut catatan sejarah tsunami yang pernah melanda wilayah sekitar Papua Barat ada 3 (tiga) peristiwa besar, yaitu: tsunami yang terjadi tahun 1937 melanda pesisir Wilayah Fakfak, tsunami Biak pada tahun 1979, dan tsunami Yapen tahun 1979 dan 1996. Berdasarkan tinggi gelombang tsunami yang pernah terjadi di wilayah Papua Barat, genangan paling tinggi yang pernah terjadi berada di daerah Manokwari, yaitu setinggi 1 sampai $5 \mathrm{~m}$.

Salah satu tempat dimana gelombang tsunami menjadi lebih dahsyat adalah di daerah teluk, karena gelombang tsunaminya akan mengalami amplifikasi dan gelombangnya bertambah tinggi. Proses amplifikasi ini akan sangat efektif pada daerah teluk yang posisinya berhadapan langsung dengan sumber tsunami. Daerahdaerah yang terletak pada teluk di Provinsi Papua Barat diantaranya adalah: Kabupaten Sorong Selatan, Kabupaten Teluk Bintuni, Kabupaten Teluk Wondama, Kabupaten Fakfak dan Kabupaten Tambrauw.

\subsection{Bahaya Tsunami di Provinsi Papua Barat}

Potensi bahaya tsunami di Papua Barat diklasifikasikan menjadi tiga (3) zona, yaitu: Zona Bahaya Tinggi, Zona Bahaya Rendah dan Zona Bahaya Aman. Dasar pembagian zona tersebut adalah: kondisi topografi kawasan pantai, bentuk pantai (teluk atau tanjung), batimetri perairan di sekitar pantai, pulau-pulau kecil sebagai penghalang pergerakan tsunami dan sudut datangnya tsunami ke arah pantai.

Zona bahaya tsunami tinggi terletak langsung berbatasan dengan laut. Zona bahaya tsunami rendah terletak pada daerah di belakang zona bahaya tinggi dan pada beberapa tempat pada daerah yang berbatasan langsung dengan laut yang bertopografi relatif tinggi. Sementara daerah aman berada di morfologi tinggi.

Bahaya tsunami tinggi di Provinsi Papua Barat yang mempunyai pelamparan cukup jauh masuk ke daratan terdapat di pantai Kota Sorong, Kabupaten Sorong, Kabupaten Sorong Selatan ke arah Teluk Bintuni yang meliputi Kabupaten Teluk Bintuni dan Kabupaten Fakfak sebelah utara (Kecamatan Bomberay). Sementara bahaya tsunami tinggi dengan persebaran tidak terlalu luas juga terdapat di sepanjang pantai Kabupaten Kaimana khususnya di Teluk Kaimana, Kapupaten Fakfak bagian barat (Kecamatan Karas dan sedikit di Kecamatan Fakfak Timur), Kota Sorong bagian barat, Kabupaten Raja Ampat, Provinsi Papua Barat bagian barat (Kab. Teluk Wondama, Kabupaten Manokwari), Provinsi Papua Barat bagian utara (Kota Manokwari, Kabupaten Manokwari dan Kabupaten Sorong).

Potensi tsunami tinggi di Kota Sorong terutama terdapat di Kecamatan Sorong Timur, sebagian besar Kecamatan di Kabupaten Sorong serta Kabupaten Sorong Selatan. Potensi tsunami tinggi untuk Kabupaten Teluk Bintuni terdapat di Kecamatan-kecamatan: Masyeta, Biscoop, Komundan, Kuri, Merdey, dan sekitarnya. Kecamatan Salawati Utara termasuk daerah yang mempunyai bahaya tinggi di Kabupaten Raja Ampat. Kabupaten Kaimana yang mempunya potensi bahaya tinggi terdapat di Kecamatan-kecamatan: Buruway, Kaimana, Teluk Arguni, Yamor dan sekitarnya.

Di Kota dan Kabupaten Manokwari, sepanjang pantai ada potensi bencana tinggi tsunami meskipun persebaran yang relatif terbatas karena topografi yang relatif tinggi. Kecamatan yang mempunyai potensi tinggi 
adalah Kecamatan Kebar dan Kecamatan Senopi. Kabupaten Mambrauw yang berpotensi tinggi berada di bagian utara, yaitu Kecamatan Abun, Kecamatan Fef dan Kecamatan Miyah. Potensi tinggi tsunami di
Kabupaten Teluk Wondama terdapat di Kecamatan Kuri Wamesa dan Kecamatan Naikere.

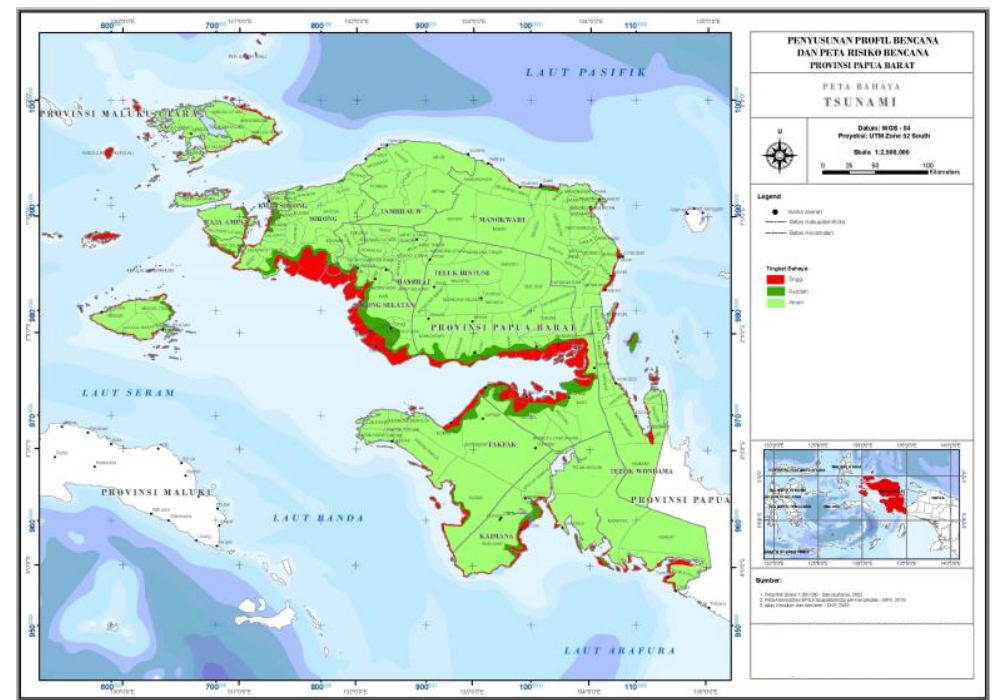

Gambar 5. Peta Bahaya Tsunami di Provinsi Papua Barat (Sumber: Analisis Data)

\subsection{Kerentanan dan Risiko Tsunami di Provinsi Papua Barat}

Untuk analisis kerentanan Provinsi Papua Barat digunakan data penduduk. Data jumlah penduduk yang tersedia di seluruh daerah di Papua Barat dalam unit area kecamatan dan data inilah yang akan dipakai sebagai parameter kerentanan. Data jumlah penduduk per kecamatan yang ada di seluruh Provinsi Papua Barat menunjukkan bahwa angka terendah adalah 276 jiwa yang dimiliki oleh Kecamatan Syujak, Kabupaten Tambrauw dan yang tertinggi adalah 57.876 jiwa untuk Kecamatan Manokwari Barat dari Kabupaten Manokwari.

Provinsi Papua Barat terdiri dari 13 kabupaten/kota dan 218 kecamatan. Sebaran data jumlah penduduk yang ada ternyata didominasi oleh jumlah yang relatif kecil. Dari 208 data jumlah penduduk yang ada, kurang lebih ada 104 data yang jumlahnya bergradasi halus mulai dari 267 sampai 2.964 (kurang dari 3.000), data no 105 sampai 137 (32 data) menunjukkan nilai bergradasi lebih tajam yaitu dari jumlah penduduk 3.166 sampai 9.492 dan kelompok yang ketiga bergradasi tajam yaitu dari data nomor 138 sampai 154 dengan jumlah penduduk mulai dari 10.273 sampai 57.876 jiwa. Bila pengelompokan ini dijadikan sebagai dasar klasifikasi tingkat kerentanan, maka dirasakan kurang baik.

Data jumlah penduduk setiap kecamatan yang ada di Provinsi Papua Barat telah digambarkan dalam suatu peta sebaran populasi. Pada peta tersebut nampak bahwa kecamatan dengan jumlah penduduknya relatif besar adalah kecamatan dengan warna merah, seperti kecamatan yang berada dibagian timur laut wilayah Provinsi Papua Barat, yaitu (Kecamatan Manokwari, Kecamatan di sebelah barat laut Papua Barat, seperti Kecamatan Sorong Timur, Aimas, Sorong Manoi, Sorong Barat, Sorong dan Kecamatan Sorong Utara, sedangkan kecamatan yang berada dibagian selatan adalah Kecamatan Bintuni, Fakfak dan Kaimana.

Kajian risiko bencana tsunami melibatkan dua faktor utama, yaitu faktor bahaya tsunami dan faktor kerentanan. Faktor bahaya tsunami dibagi menjadi 3 kelas/zona. Ketiga zona tersebut adalah zona bahaya tinggi, zona bahaya rendah dan zona aman. Disini, faktor kerentanan hanya melibatkan parameter kepadatan penduduk (jumlah penduduk). Identifikasi tingkat kerentanan berdasarkan pada kondisi jumlah penduduk per kecamatan telah menghasilkan 3 (tiga) tingkat kerentanan, yaitu tingkat kerentanan rendah (jumlah 
penduduk $<2.423$ jiwa), kerentanan sedang (2.424 - 13.459 jiwa) dan kerentanan tinggi (>13.459 jiwa). Berdasarkan kombinasi antara kedua faktor diatas, maka akan dapat ditentukan tingkat risiko bencana Daerah Provinsi Papua Barat.

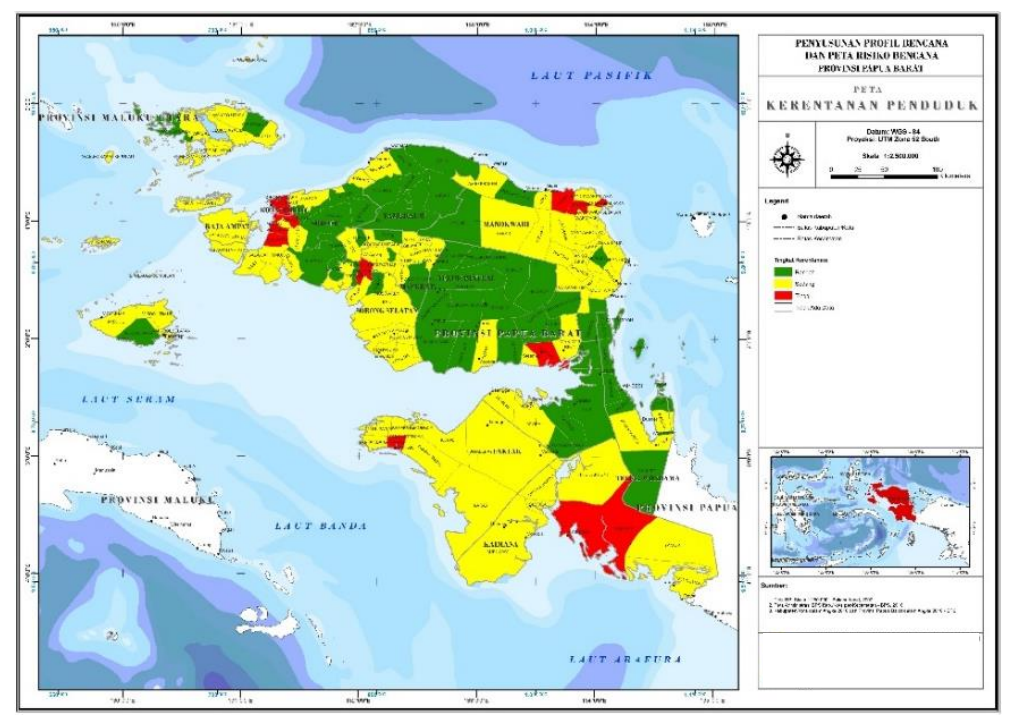

Gambar 6. Peta Kerentanan Wilayah Papua Barat (Sumber: Analisis Data)

Penentuan tingkat risiko dilakukan melalui penggabungan faktor bahaya dan kerentanan. Mengingat pelamparan (sebaran) zona bahaya tsunami hanya berada di sepanjang pantai dengan dimensi lebar yang relatif sempit, maka dalam menentukan tingkat risiko tidak berdasarkan luasan unit kecamatan. Penentuan zona tingkat tsunami berdasarkan pada kombinasi tingkat bahaya dengan nilai tingkat kerentanan dari kecamatan terkait, akhirnya zona risiko tidak mengikuti batas administrasi kecamatan. Adapun ketentuan penggabungan dari kedua faktor tersebut adalah seperti terlihat pada tabel berikut.

Tabel 2. Matriks Faktor Bahaya dan Kerentanan

\begin{tabular}{|c|c|c|c|c|}
\hline \multirow{2}{*}{\multicolumn{2}{|c|}{$\begin{array}{l}\text { Parameter } \\
\text { Risiko }\end{array}$}} & \multicolumn{3}{|c|}{ Kerentanan } \\
\hline & & Rendah & Sedang & Tinggi \\
\hline \multirow{3}{*}{$\begin{array}{l}\frac{0}{\mathrm{~d}} \\
\frac{\mathrm{c}}{\mathrm{N}} \\
\text { m. }\end{array}$} & Aman & Aman & Aman & Aman \\
\hline & Rendah & Rendah & Rendah & Sedang \\
\hline & Tinggi & Sedang & Tinggi & Tinggi \\
\hline
\end{tabular}

Hasil identifikasi tingkat risiko bencana tsunami yang telah dilakukan menghasilkan 4 (empat) kelas/tingkatan risiko dan penyebaran zona risikonya seperti tertera pada peta risiko bencana tsunami Wilayah Papua Barat.
Persebaran zona risiko yang terlihat pada Peta Risiko Bencana, menunjukkan bahwa zona risiko dengan lebar zona risiko yang cukup lebar adalah terletak di sepanjang pesisir di Teluk Bintuni dan di pesisir Kabupaten Sorong Selatan. Hal ini terjadi karena pada daerah ini morfologi pesisirnya relatif landai. Lain halnya dengan lebar zona berisiko di pesisir utara kepala burung (pesisir Kota Sorong, Kabupaten Sorong, Tambrauw dan Manokwari), dimana zona risiko tsunami relatif sempit, bahkan hanya terdapat dalam area yang kecil-kecil karena morfologi pesisirnya yang relatif terjal.

Berdasarkan luas area berisiko tinggi, ternyata Kabupaten Bintuni merupakan kabupaten yang memiliki area berisiko tinggi terluas, yaitu dengan luas $116.728 \mathrm{Ha}$ atau $5,61 \%$ dari luas keseluruhan wilayah Bintuni. Sedangkan Kabupaten Tambrauw merupakan kabupaten dengan wilayah berisiko tingginya yang paling kecil dengan luas $2.076 \mathrm{Ha}$ atau $0,32 \%$ dari seluruh luas wilayahnya. Bila dilihat dari besar persentase luasnya, maka Kota Sorong yang mempunyai persentase wilayah terluas dari seluruh luas wilayah kota/kabupatennya, yaitu kurang lebih $14,19 \%$ dari seluruh wilayah administrasi Kota Sorong. Urutan kabupaten berdasarkan besar luas wilayah berisiko tinggi dapat dilihat pada Tabel 3. 
Tabel 3. Daftar Luas Area Berisiko Tinggi dari Setiap Kabupaten/Kota yang Ada di Provinsi Papua Barat

\begin{tabular}{|c|c|c|c|c|}
\hline \multirow{2}{*}{ KAB. } & \multicolumn{4}{|c|}{ TINGKAT RISIKO } \\
\hline & Tinggi & $\begin{array}{c}\% \\
\text { Tinggi }\end{array}$ & Sedang & Rendah \\
\hline Bintuni & 116728 & 5.61 & 112773 & 169943 \\
\hline Kaimana & 86471 & 5.71 & 11399 & 29946 \\
\hline Sorong Sel & 72934 & 12.87 & 80008 & 95102 \\
\hline Raja Ampat & 64464 & 8.27 & 60263 & 11553 \\
\hline Fakfak & 61545 & 5.6 & & 35191 \\
\hline Sorong & 51830 & 6.65 & 82543 & 57897 \\
\hline Manokwari & 23041 & 1.78 & 10351 & 5749 \\
\hline $\begin{array}{l}\text { Kota } \\
\text { Sorong }\end{array}$ & 4222 & 14.19 & 2350 & \\
\hline Wondama & 2645 & 0.47 & 38064 & 9314 \\
\hline Tambrauw & 2076 & 0.32 & 5166 & \\
\hline
\end{tabular}

(Sumber: Analisis Data)

Bila dilihat secara lebih detail lagi pada setiap kabupatennya, kecamatan di Kabupaten Fakfak yang mempunyai area berisiko tinggi terbesar adalah Kecamatan Karas dengan luas $22.037 \mathrm{Ha}$ dan Kecamatan Fakfak Tengah mempunyai area berisiko tinggi terkecil yaitu dengan luas 51,5 $\mathrm{Ha}$. Bila dilihat dari prosentase luas area berisiko tinggi, Kecamatan Kokas mempunyai area berisiko tinggi yang paling besar, yaitu sebesar 13,3\%.

Kecamatan dalam Kabupaten Kaimana yang tidak memiliki area berisiko tinggi, ada tiga kecamatan yaitu Kecamatan Arguni Bawah, Kambrau dan Kecamatan Yamor, sedangkan kecamatan dengan area berisiko tinggi paling banyak adalah Kecamatan Teluk Etna sebesar 24,7\% dari luas wilayah kabupatennya. Kota Sorong memiliki kecamatan dengan area berisiko tinggi $100 \%$, yaitu Kecamatan Sorong Kepulauan. Kabupaten Manokwari yang mempunyai jumlah kecamatan terbanyak diantara kabupaten lainnya di Papua Barat, meskipun berhadapan dengan zona rawan terjadinya gempabumi besar di sebelah utaranya, ternyata banyak kecamatan yang tidak termasuk berisiko tinggi. Hal ini dikarenakan wilayah pesisirnya mempunyai morfologi cukup terjal. Meskipun begitu terdapat kecamatan yang memiliki area berisiko tinggi 60,68\% yaitu Kecamatan Manokwari Timur.

Satu-satunya kabupaten yang tidak memiliki area yang terancam tsunami adalah Kabupaten Maybrat. Hal ini disebabkan Wilayah Maybrat terletak jauh menjorok ke daratan tanpa pesisir. Kabupaten lainnya yang terbebas dari area berisiko tinggi adalah Kabupaten Tambrauw. Satu-satunya kecamatan yang mempunyai area berisiko tinggi adalah Kecamatan Sausapor dengan luas 3,59\%. Meskipun demikian, wilayah kecamatan yang berisiko tinggi ini berpotensi terkena tsunami dengan intensitas tinggi.

Banyak kecamatan di Kabupaten Raja Ampat yang wilayahnya $100 \%$ berisiko tinggi, seperti Kecamatan Kepulauan Ayao, Kofiau dan Kecamatan Waigeo Barat Kepulauan, sedangkan Kecamatan Kepulauan Sembilan memiliki area berisiko sedang 100\%. Kabupaten Sorong memiliki banyak kecamatan dengan area berisiko tinggi tetapi dalam prosentasi yang relatif kecil, kecamatan yang mempunyai area berisiko tinggi terbesar adalah Kecamatan Segun yaitu sebesar 35,67\%. Kabupaten Sorong Selatan mempunyai 4 kecamatan yang beririsiko tinggi, yaitu Kecamatan Inanwatan, Kais, Kokoda dan Kecamatan Taminabuan. Sedangkan Kabupaten Teluk Bintuni mempunyai 6 kecamatan yang berisiko tinggi, yaitu Kecamatan Aroba, Babo, Bintuni, Manimeri, Sumuri dan Kecamatan Tomu, dimana Kecamatan Babo yang mempunyai luas area berisiko tinggi terbanyak, yaitu 99,68\%. Terakhir adalah Kabupaten Teluk Wondama, dimana satu-satunya kecamatan yang memiliki wilayah berisiko tinggi adalah Kecamatan Wasior (7,28\%). 


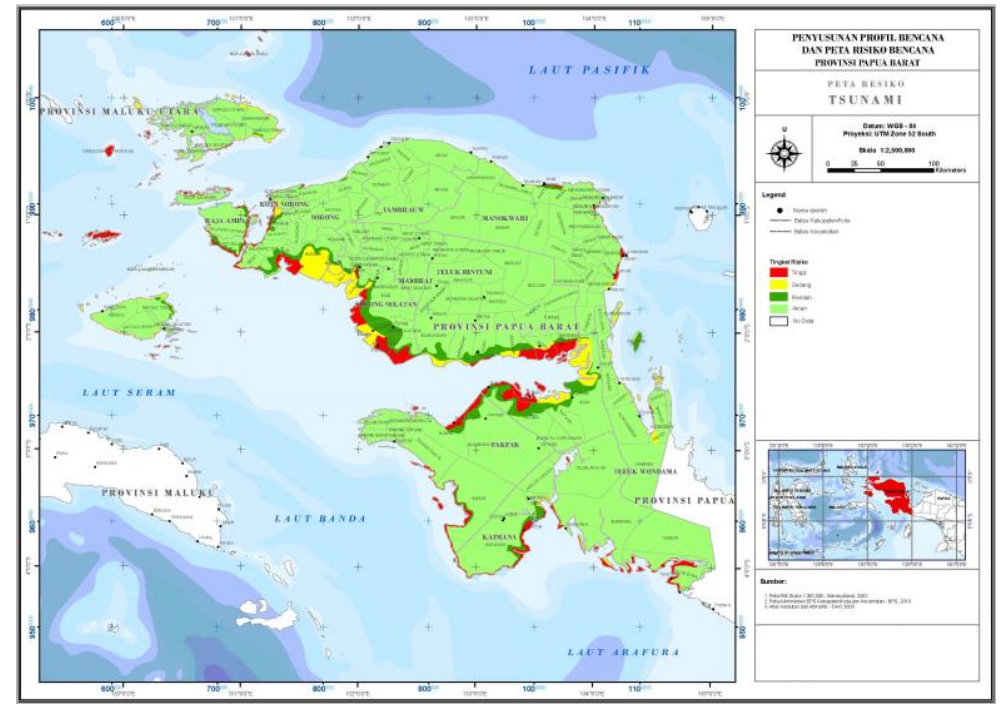

Gambar 7. Peta Risiko Bencana Tsunami Wilayah Papua Barat (Sumber: Analisis Data)

\section{KESIMPULAN}

Dari hasil pembahasan di atas bisa disimpulkan sebaga berikut:

- Bahaya tsunami tinggi di Provinsi Papua Barat yang mempunyai pelamparan cukup luas terdapat di pantai Kota Sorong, Kabupaten Sorong, Kabupaten Sorong Selatan, Kabupaten Teluk Bintuni dan Kabupaten Fakfak sebelah utara (Kecamatan Bomberay).

- Persebaran tsunami tidak terlalu luas juga terdapat di sepanjang pantai Kabupaten Kaimana khususnya di Teluk Kaimana, Kapupaten Fakfak bagian barat, Kota Sorong bagian barat, Kabupaten Raja Ampat, Provinsi Papua Barat bagian barat (Kab. Teluk Wondama, Kabupaten Manokwari), Provinsi Papua Barat bagian utara (Kota Manokwari, Kabupaten Manokwari dan Kabupaten Sorong).

- Analisis kerentanan Provinsi Papua Barat digunakan data penduduk dalam unit wilayah kecamatan, menghasilkan 3 (tiga) tingkat kerentanan, yaitu tingkat kerentanan rendah (jumlah penduduk $<2.423$ jiwa), kerentanan sedang (2.424 13.459 jiwa) dan kerentanan tinggi (>13.459 jiwa).

- Kerentanan tinggi berada di bagian timur laut wilayah Provinsi Papua Barat, yaitu (Kecamatan Manokwari, Kecamatan di sebelah barat laut Papua Barat, seperti Kecamatan Sorong Timur, Aimas, Sorong Manoi, Sorong Barat, Sorong dan Kecamatan Sorong Utara, sedangkan kecamatan yang berada di bagian selatan adalah Kecamatan Bintuni, Fakfak dan Kaimana.

- Kajian risiko bencana tsunami melibatkan dua faktor utama, yaitu faktor bahaya tsunami dan faktor kerentanan.

- Persebaran zona risiko tinggi yang cukup lebar adalah terletak di sepanjang pesisir di Teluk Bintuni (Kabupaten Teluk Bintuni dan Kabupaten Fakfak sebelah utara) dan di pesisir Kabupaten Sorong Selatan, Kota Sorong, Kabupaten Sorong, karena pada daerah ini morfologi pesisirnya relatif landai.

- Berdasarkan luas area berisiko tinggi, Kabupaten Bintuni merupakan kabupaten yang memiliki area berisiko tinggi terluas, yaitu dengan luas $116.728 \mathrm{Ha}$ atau $5,61 \%$ dari luas keseluruhan Wilayah Bintuni.

- Bila dilihat dari besar persentase luasnya, maka Kota Sorong yang mempunyai persentase wilayah terluas dari seluruh luas wilayah kota/kabupatennya, yaitu kurang lebih $14,19 \%$ dari seluruh wilayah administrasi Kota Sorong.

\section{DAFTAR PUSTAKA}

BNPB. 2012. Peraturan Kepala Badan Nasional Penanggulangan Bencana Nomor 02 tahun 2012 Tentang Pedoman Umum Pengkajian Risiko Bencana.

BPS Provinsi Papua Barat. 2018. Provinsi Papua Barat Dalam Angka.

Engdahl, E.R. 2006. Application of an Improved Algorith to High Precision 
Relocation of ISC Test Events: Physics of the Earth and Planetary Interiors. v. 158: 14-18.

Hadi, A.I., M. Farid, dan Y. Fauzi. 2012. Pemetaan percepatan getaran tanah maksimum dan kerentanan seismik akibat untuk mendukung Rencana Tata Ruang dan Wilayah (RTRW) Kota Bengkulu. Jurnal IImu Fisika Indonesia, Vol. 1 (2012): 81-86.

Kementerian Pekerjaan Umum. 2017. Peta Bahaya Gempa Indonesia 2017.

KLH. 2007. Analisis Potensi Bencana Alam di Papua dan Maluku (Tanah Longsor Banjir - Gempabumi - Tsunami). Laporan.

Latief, H. 2000. Tsunami Catalog and Zoning in Indonesia, Journal of Natural Disaster. 22(1): 25-43.

Naryanto, H.S. 2008. Analisis Potensi Kegempaan dan Tsunami di Kawasan Pantai Barat Lampung Kaitannya dengan Mitigasi dan Penataan Kawasan, Jurnal Sains dan Teknologi Indonesia. 10(2): 7177.

Naryanto, H.S. 2017. Potensi Gempa dan Tsunami di Kabupaten Banggai Laut, Provinsi Sulawesi Tengah. Jurnal Sains dan Teknologi Mitigasi Bencana. 12(2): 46-60.

Natawidjaja, D.H. 2007. Tektonik Setting Indonesia dan Pemodelan

Gempa dan Tsunami Pelatihan Pemodelan Tsunami Run-up. RISTEK. 20 Agustus, 2007.

Pratomo, R.A. dan I. Rudiarto. 2013. Permodelan Tsunami dan Implikasinya
Terhadap Mitigasi Bencana di Kota Palu. Jurnal Pembangunan Wilayah dan Kota. 9 (2): 174-182.

Prawiradisastra, S. dan E.W. Santoso. 1997. Identifikasi Gempa Biak 17 Pebruari 1996 Sebagai Upaya Program Mitigasi Bencana. Jurnal Alami. 2(3): 2931.

Puntodewo, S.S.O., R. McCaffrey, E. Calais, Y. Bock, J. Rais, C. Subarya, R. Poewariardi, C. Stevens, J. Genrich, Fauzi, P. Zwick, and S. Wdowinski. 1994. GPS Measurenments of Crustal Deformation within the Pacific-Australia Plate Boundary Zone in Irian Jaya, Indonesia. Tectonophysics, 237(3-4): 141-153.

Puspito, N. 2002. Tsunami and Earthquake Activity in Indonesia. Proceedings of the International Workshop on Local Tsunami Warning and Mitigation. PetropavlovskKamchatsky, Russia. pp. 138-145.

Rahmawati, N.I., B. J. Santosa, W. Setyonegoro, dan B. Sunardi. 2017. Pemodelan Tsunami di Sekitar Laut Banda dan Implikasi Inundasi di Area Terdampak. Jurnal Sains Dan Seni Pomits 6(2): B33B36.

Undang-Undang Republik Indonesia Nomor 24 Tahun 2007 Penanggulangan Bencana. 